\title{
Counseling Services in Human Rights Problems and Its Interconnection to the Gender Issues
}

\author{
Ida Umami ${ }^{1}$, Ali Mashari ${ }^{2}$ \\ \{alidaumami@yahoo.co.id ${ }^{1}$, alimashari24@gmail.com ${ }^{2}$ \} \\ ${ }^{1}$ IAIN Metro Lampung, Indonesia \\ ${ }^{2}$ STKIP Al Islam Tunas Bangsa Lampung, Indonesia
}

\begin{abstract}
Human is created by the God as perfect creature and granted with high standing and prestige better that the other creatures and apart of them is materialized by human right. The materialization of human right must be in line with execution of the obligation and responsibility applied universally. In Al-Qur'an's perspective, man and women are equal and have the same position except their belief and fear of God. Women have many potential in improving the quality of their life and showing the directions and chances for social, economic, politic, and personal developments. Many human's quality in supporting a positive life being should be promoted personally by women and men. However, many beliefs and attitudes in the society about women are affected by myths and stereotypes. In this case, the effect of social and cultural beliefs which hinder the women development and status can be changed. Therefore, the appropriate formulation of women empowerment for gender gap is necessary in order to promote the equality of men and women in the law and society as the only distinctions is the their fear of God.
\end{abstract}

Keyword: Counseling Services, Human Rights Problems

\section{Introduction}

The discussion regarding the most basic rights possessed by humans to fight for underlies the birth of a joint charter in the form of the Magna Charta agreed to in 1215 as the recognition and treatment to provide security and protection to the nobility and also the clergy. In later developments, the agreement was followed by a declaration including the protection of basic human rights.

There are many conditions and developments for fundamental human rights such as in the form of independence, equality and brotherhood in several aspects of life. They further led to the demand to develop towards the growth of democratic ideology which is based on fundamental human rights for all of people and created important events to recognize universal human rights such as the emerge of the "Universal Declaration of Human Rights" as general statement about the most basic rights for human being.

This declaration was then reinforced by the agreement which was carried out on December 10, 1948 in the UN General Assembly session which discussed 30 points and provisions on basic human rights[1]. However, it is the fact that there are still violations of basic human rights, especially related to gender issues. Women are often victims of violations by men in household affairs, livelihood problems and in government. In this case, Islam through the 
Koran has given an equal position between men and women in their life with the only difference is more about their devotion to Allah SWT, not merely physical matters.

The Qur'an, as a guide to human life, places women in an honorable position as reflected in several authentic traditions. The existence of several violations of basic human rights is also due to a narrow understanding of the roles, functions and equality relations between men and women. This misunderstanding also underlies various violence behaviors, especially related to gender issues that have become a profound impact on the society, state and nation.

\section{Discussion}

Basic human rights are included in official documents of the world declaration related to human rights carried out in Tehran in May 1968, U.N. Doc.A / CONF.32 / 41, in No. E. 68, XIV of Chapter 1 which states that all humans are born with freedom and have the same dignity and basic human rights. Humans are destined to be born with a mind and are born to mingle in different tribes, races and religions in brotherhood[2]. Simillarly stated by Ruswiati that from the chronology of time and history, international law has been witnessed by the existence of an international collective agreement text that provides protection of basic human rights globally including the people in Indonesia[3]. Therefore, basic human rights have indeed used the human nature basis and legal basis as a strong foundation.

Basic human rights commonly referred to as human rights in Indonesia are included in the preamble of the 1945 Constitution as an embodiment of the Pancasila values as a main source of law in teachings of the basic human rights such as:

1. Recognition of the most basic human rights which includes the obligations that must be implemented. In general, basic human rights in individuals and groups of people and nations are based on human dignity and justice (1st paragraph).

2. The highest recognition from the Indonesian people to realize an independent, united, sovereign, fair and prosperous nation. This embodiment and shared ideals are included as the substance of basic human rights in the political, economic and socio-cultural fields as well as security (2nd Paragraph)

3. The recognition of basic human rights in having freedom in determining, choosing religion, the socio-cultural and political fields in society and nation (3rd Paragraph).

4. Recognition of human rights and obligations as citizens in the community and state, which is obliged to carry out the achievement of national goals in all fields such as the economic, political, socio-cultural, defense and security.

Based on the content and meaning in the preamble of the 1945 Constitution, it is clear that basic rights are respected in Indonesia. It also needs to be realized in accordance with citizen responsibilities equally. Basic human rights and obligations of citizens are specifically regulated in the articles and contents of the 1945 Constitution.

In the perspective of Islam, Abul A'la Al-Maududi states that the basic rights granted by Allah SWT to humans are also included in the text of the Qur'an, such as[3]:

1. Humans freedom in the faith according to their beliefs.

2. Right to Own Wealth

3. Right to have Different Opinions

4. Private Property right

5. Right to have Freedom of Organization

6. Right to life

7. Right to have Independence in Thinking and Giving opinions[4]. 
In Islam, basic human rights use an essential foundation in their implementation. Basic human rights are implemented in harmony with the fulfillment of their responsibilities as citizens. The exercise of basic rights cannot be absolute, because the prosecution of such implementation absolutely means violations of the same basic human rights for others. Basic human rights according to Ruswiati Surya Saputra (2006) are also listed in paragraph two of the convention relating to children's rights stating that: the state must take appropriate steps to ensure that children are in the protection of the state from all forms of violence and legal injustice based on social status, religious beliefs, expressed opinions, or beliefs of parents, legal guardians, or family members[4].

The various descriptions above can be used as a basis for thinking, arguing and behaving that must not be tampered with or by other people. However, these basic rights must be accompanied by high accountability for the fulfillment of obligations. Humans are basically physical and spiritual beings who have perfection in physical and psychological form. Human beings have a high degree of piety, piety and as khalifah on earth, and voters of basic human rights. In fact human beings having various potentials need to develop more optimally by realizing the goals of education especially in empowering women so that they can play a greater role and participate in life both in personal, family, community and national. However, there are many problems related to the implementation of human rights needed to have efforts to overcome. One of solutions is counseling services.

Counseling services are very urgent in overcoming the problem of violations of human rights, especially those dealing with gender issues. This is because these problems can be considered as part of the effects of pressure both physical and psychological life. Of course, in such conditions, a person really needs help that allows him to overcome the problems and be able to make various choices in making decisions.

Psychological pressure in various human rights violations issues and especially related to gender issues according to Ida Umami has many negative effects on family and community life. Physical effects in some cases are in the form of heavy workload which multiplies while having inadequate proper appreciation[5]. Such conditions are very influential on a person's psychology which can lead to many problems such as feelings of dissatisfaction, resentment, mental burdens and often lead to prolonged depression and stress. In these kind of conditions, counseling guidance services are needed.

The problem of human rights violations at this time happens almost in all aspects of life. High crime, sexual harassment, violence in public places, social crime and the rise of online prostitution have an impact and moral burden on individuals and society. Therefore, systematic steps in the effort to develop the ability to deal with life problems such as counseling in the community is needed.

Counseling services in relation to the development of self potential and the ability to face life problems can be carried out through various services both individual and group. Ida Umami (2017] argues that individual services can be in the form of providing information, emotional reinforcement, developing self esteem until interviews in problem solving and discussing various possibilities in dealing with problems, whereas as a group can utilize shared strength as a basis for self-development so that they are able to develop positive attitude in relation in living together[2].

Counseling as one of the efforts to empower women is part of the strengthening aiming in building community life through guidance and rules in the nation and realizing progress in all fields. Therefore, the vision of developing women's empowerment is the gender equality and justice in family, community, and national." Essentially, the success of women's empowerment lies in five main agendas: (1) improving the quality of life of women in various 
strategic fields, (2) promoting socialization of equality and gender justice, (3) eliminating all forms of violence against women, (4) enforcement basic human rights for women, (5) enabling and enhancing the independence of women's institutions and organizations. These five aspects are the main objectives of the development of women's empowerment. Therefore, gender mainstreaming should be implemented in all aspects of women's policies and lives.

The term gender is often confused and equated with female gender. Essentially, gender refers to male and female. The concept of gender is basically a set of attributes, roles and responsibilities, functions, things and behaviors inherent in men and women due to cultural or environmental conflicts. Therefore, in society, men are always portrayed through masculine traits that describe physical strength and might while women are more likely to be feminine with a gentle and patient nature. This masculine and feminine nature is more of a social construction, and not a natural thing (Ministry of National Education, 2003). So, basically, the concept of gender is a social concept. The terms femininity and masculinity associated with the term gender are related to a number of psychological and behavioral characteristics that have been studied by a person through his complex socialization experience[6].

The difference in masculine and feminine traits then creates various drawbacks, such as:

1. There is a heavier workload on women

2. The existence of discrimination and violent behavior towards women

3. The existence of a woman's perception as just a complement to sufferers

4. Stereotypes on women such as additional partner and so on

In general, the issue of gender in particular the existence of gaps in roles can be considered as an ongoing problem. Gender disparity is seen as a necessity and natural as placing women in positions of powerlessness and do not have important bargaining positions. The existence of these views and perceptions of women weaker than men lead to the general belief in community that women should live in the household, while men should go out of the house to make a living[7].

Understanding of the roles and functions above is certainly not in line and contrary to the concept of basic human rights. In general Indonesia has five important objectives in relation to the issue of gender equality as follows:

1. Make various efforts in ending all forms of violence and discrimination against women by men. As stated in Presidential Instruction No. 9 of 2000 concerning gender equality mainstreaming. All forms of violence, especially domestic violence must end.

2. Work to eliminate violence against women, especially in terms of human trafficking, exploitation of women and other related problems.

3. Eliminating and eliminating all practices that could endanger women such as early marriage that could damage the future of women. Early marriage will also endanger women because there is no readiness both physically and mentally and especially will endanger reproductive health.

4. Giving rewards to women for services and work performed in the household and in particular giving rights to domestic servants such as giving leave and so on.

In general, women's resources are not as advanced as their male resources, especially in terms of academic resources. Therefore, it is necessary to unify perceptions and renewal of the empowerment format by considering the issue of gender disparity. In general there are several factors associated with this problem:

1. Factors related to Access

Women's empowerment should be done as much as possible so that women have the competitiveness and ability to access many existing opportunities and use them optimally in the social and government, academic and non-academic fields. The efforts in increasing the 
role of women in various fields of family and community needs to be improved for the better future.

In addition, it is necessary to do some studies and research on gender issues as an effort to improve the role of women in various aspects of life in society. Several stages of efforts in improving the quality and relevance of education as well as job descriptions and careers based on gender equality must continue to be developed and supplemented through relevant programs for the realization of gender equality in the field of education or in other fields related to human life in general.

\section{Control and Supervision factors as well as Benefit}

Aspects of human life include various aspects of life, especially in the work related activities to the livelihoods and positions that are largely controlled by men and in many academic aspects that lead to a tendency for gender inequality. This refers to the lack of influence of the control factors and the mind of women because decision making is still dominated by men.

\section{Participation Factors}

Currently, the participation of women in most fields of life has shown significant development with various efforts to encourage greater quality of participation. However, in the fact that in developing society, the level of women's participation still needs to be improved in various aspects and fields of life both personal, and social life as well as in the role of nation. Responsive and active participation of women can further encourage the achievement of each goal towards the realization of gender equality.

\section{Conclusions}

Based on the description and study above, it can be concluded that problems related to violations of basic human rights especially those related to gender, occur in all areas of life. Counseling services become an alternative solution in overcoming problems arising through the development of individual abilities and strengths in determining and decisions making related to the problems they experience. In the perspective of Islam as a religion of rahmatan lil alamin, it emphasizes the existence of equality between men and women. Islam places women in a noble place and has the same dignity and status. In the view of the Qur'an, humans are measured by their faith and devotion. Therefore, the understanding, perception and belief that women have the ability to put themselves and their equal potential with men in various fields of life should be internalized. Men and women are also blessed with the same dignity and human rights. The appropriate condition and alignment could possibly promote more help and strengthen each other in achieving all the goals of happiness in life in the world and hereafter as god's promises in the Qur'an.

\section{References}

[1] Widjaja H.A.W, Penegakan Hak-hak Asasi Manusia. Jakarta: Rineka Cipta, 2000.

[2] Ida Umami, Bimbingan Konseling ( Teori, Praksis dan Praktik). Jakarta: Kukaba, 2017.

[3] Abu A'la Al-Maududi, Manusia dalam Al-Quran. Jakarta: Rineka Cipta, 2008.

[4] R. Suryasaputra, Perlindungan Hak Asasi Bagi Kelompok Khusus terhadap 
Diskriminasi dan Kekerasan. Jakarta: Restu Agung, 2006.

[5] I. Umami, Hak asasi manusia dan Gender dalam Prespektif Pendidikan Islam. Lampung: STAIN Jurai Siwo Metro, 2015.

[6] S. Sadli, “Pengantar Tentang Kajian Wanita”. Dalam Ihromi. Kajian Wanita dalam Pembangunan. Jakarta: Obor, 2005.

[7] S. Djajanegara, Kritis Sastra Feminis: Sebuah Pengantar. Jakarta: Gramedia, 2010. 